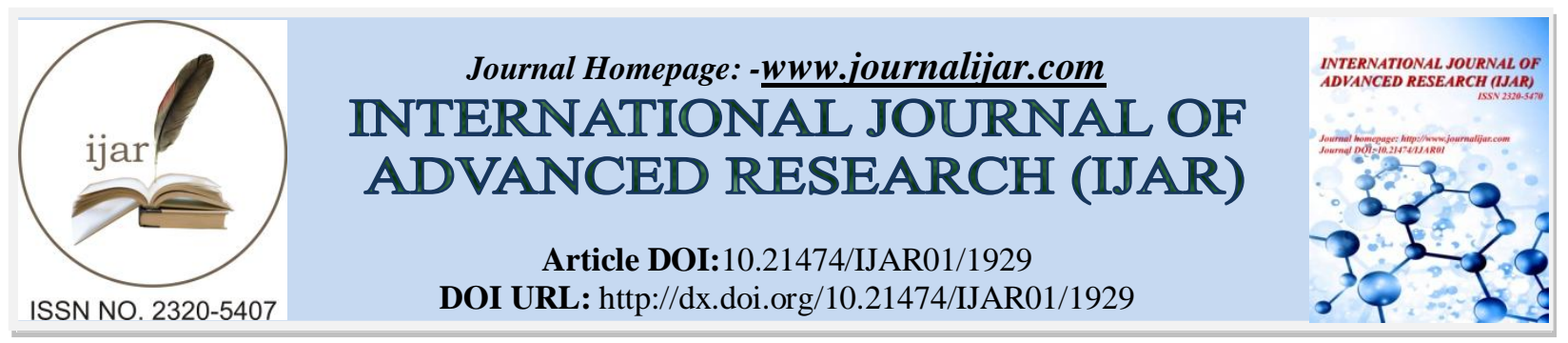

RESEARCH ARTICLE

UPDATE ON MYCOSIS FUNGOIDES AND SEZARY SYNDROME.

Charles Joseph Haddad M.D and Judella Haddad-Lacle M.D.

Associate Professors University of Florida.

\section{Manuscript Info}

Manuscript History

Received: 12 August 2016

Final Accepted: 22 September 2016

Published: October 2016

Key words:-

\section{Abstract}

Mycosis Fungoides and Sezary Syndrome make up between 65-92\% of cutaneous T- cell lymphomas.

There is a wide range of severity in patients with Mycosis Fungoides. The diagnosis of these disorders may be difficult since they may have similarities and responses to treatment of other more common skin disorders.

Biopsying different areas before starting treatment aid in the diagnosis of these disorders.

Treatment of cutaneous lymphomas varies widely and caution must be taken not to over treat.

Copy Right, IJAR, 2016,. All rights reserved.

\title{
Update on Mycosis Fungoides and Sezary Syndrome:-
}

Mycosis Fungoides and Sezary Syndrome make up between 65-92\% of cutaneous T-cell lymphomas. These are now the most common type of adult lymphomas. Sezary Syndrome is frequently more aggressive with tumors. ${ }^{1,2}$

\section{There is a wide range of severity in patients with Mycosis Fungoides:-}

Some patients have only minor scaling areas with erythema. These areas may partially respond to topical steroids and occasionally may resolve spontaneously. Other patients with Mycosis Fungoides may develop large mushroom shaped skin lesions that are not responsive to topical treatments.

The diagnosis of these disorders may be difficult since they may have similarities and response to treatment of other more common skin disorders such as eczema, psoriasis and atopic dermatitis. The lesions of both Mycosis Fungoides and Sezary Syndrome may be single or multiple and may affect any area of the body, but most frequently the face, trunk, inner arms and legs, and scalp. They may be patches or plaque and are usually associated with itching, scaling and redness.

Clinical features including presentation, morphology, staging, histology, immunophenotype and molecular features must be considered to minimize false positive and false negative diagnosis.

Diagnosis of these disorders is aided by biopsying different areas and should be performed several weeks after treatment has been discontinued or before starting treatment. Patients with Sezary Syndrome will show Sezary cells in peripheral blood. These are described as lymphocytes that are hyper convoluted and cerebeliform.

The staging of cutaneous lymphomas including Mycosis Fungoides and Sezary Syndrome are based on the description of the tumor lymph node involvement, metastasis and blood involvement. (TNMBsystem). 
Treatment of these cutaneous lymphomas varies widely and caution must be taken not to over treat. For small lesions it may suffice to treat with corticosteroid creams or ointments, or nitrogen mustard. Phototherapy and interferon have also been successful. Other treatment options include radiation treatment, skin electron radiation, retinoids, imiquinod and biological such as alentuzumab and intralesional injections of Interferon. Extracorporeal photopheresis (ECP) has an immunomodulating affect that leads to expansion of peripheral blood dendritic cell population and enhanced THI immune response, and has an excellent side effect profile.

\section{References}

1. Habif TP. Premalignantnonmelanoma skin tumors. In: Habif TP. Clinical Dermatology: A color Guide to Diagnosis and Therapy. $6^{\text {th }}$ ed. Philadephia, PA: Elsevier; 2016:809-852.

2. Ally MS, Robinson A. A review of the solitary cutaneous T-cell lymphomas. J CutanPathol. 2014; 41-(9): 703-714.

3. Sidiropoulos KG, Martinez-Escala ME, Yelamos O, Guitart J, Sidiropoulos . Primary cutaneous T-cell lymphomas: a review. J ClinPathol. 2015 Dec; 68(12): 1003-10.

4. Zic JA. Extracorporeal Photopheresis in the Treatment of Mycosis Fungoides and Sezary Syndrome. DermatolClin. 2015 Oct; 33(4):765-766. 